REGE

28,1

\section{Call for papers: sustainability transitions in the Global South - learnings from COVID-19 and future directions}

Sustainability transitions (ST) is an evolving, vibrant research field - approximately 1,100 papers on the subject have been published in 2019 and 2020 in journals indexed in the Scopus database, with a fast and steady growth in the last decade (Kohler et al., 2019). The theories and empirical evidence of sociotechnical transitions are widely debated by academics, policy makers and practitioners to understand and promote systemic transformations in society. Transitions are meant to allow more sustainable ways of production and consumption in different sociotechnical systems such as energy, mobility and food, promoting climate change mitigation (IPCC, 2018) and just transitions (Swilling \& Annecke, 2012). Although ST has become an impressively wide research field, with abundant empirical evidence, its main focus remains in studying European societies. Even when other parts of the globe are visited empirically, the theories and frameworks continued, till date, to have a "Western bias" (Kohler et al., 2019; Ramos-Mejía, Franco-Garcia, \& Jauregui-Becker, 2018; Ghosh \& Schot, 2019; Marx, Mello, Zolbovicius, \& Lara, 2015). It is now established that scholars working in or on Global South contexts may need to ask different research questions and answer those questions keeping in mind different socio-political, economic and cultural conditions. The very experience of conducting research may also be different, resulting in very different hurdles in both empirical and methodological approaches used in research on the Global South, compared to those in the Global North.

Aiming to rectify this bias and gain deep insights from the knowledge and competence base on sustainability transitions from around the world, the Transitions in Global South (TGS) thematic group was created in 2015, as part of the broader STRN (Sustainability Transitions Research Network) community. By making the STRN community more international and diverse, TGS aims to highlight low- and middle-income countries' viewpoints in addressing the very challenging and complex phenomena that connect local and global, rich and poor. Since the Global South is not monolithic, TGS also aims to showcase the diversity of countries' viewpoints. TGS is now a community of more than 300 scholars and practitioners, with a Twitter follower base of more than 600 individuals (as of 20th November 2020). A motivated group of 10 scholars came together and organised a webinar series (7 monthly webinars between June and December 2020) on the contemporary topic of "Transitions in the Global South in times of Covid-19".

COVID-19, from a transitions perspective, is a major "landscape shock" that resulted in major and rapid shifts in the economy, politics, human and natural world. Countries all around the world have embraced various measures to prevent the spread of the virus by a variety of restrictions and lockdown measures. From a sociotechnical system perspective, the virus very soon became much bigger than a "health system issue" and impacted other systems like mobility, education, food, fashion, housing, etc. (Belhadi et al., 2020; Skare et al.,

(C) Adriana Marotti de Mello, Katharina Josefa Friedhilde Schiller, Bipashyee Ghosh, Joyashree Roy and Mark Swilling. Licensed re-use rights only 
2020; McMaster et al., 2020). Recent reports suggest that that the world is more unequal because of COVID-19 and the poorer nations took the worst hit (Cannon, 2020). With the COVID-19 crisis impacting all aspects of life and societies around the globe, we, as transitions scholars, are grappling with new, urgent questions:

(1) What kinds of strategies are being employed by people/organisations in the Global South to deal with the (social and economic) impacts of COVID-19?

(2) How can we contribute to developing both short-term and long-term strategies to cope with acute emergencies caused by COVID-19 as well as its future impact on societies, environments and economies?

(3) How sustainable will long term social and technological transitions be in a postCOVID-19 world?

These are some of the questions we asked our monthly panelists in the webinar series from different regions of the Global South - Latin America, Africa and Southeast Asia. Inspired by the insightful discussions with researchers, and with the aim of solidifying the ongoing learnings as well as expanding this knowledge base, REGE is inviting authors to submit papers with relevant contributions to the special issue on Sustainability Transitions in the Global South, considering post-Covid-19 context and challenges. We welcome contributions towards the following overarching questions:

(1) What are examples of sustainability transitions in the Global South due to COVID-19? How sustainable are these ongoing transitions?

(2) What can be done to ensure socially and ecologically just transitions in the Global South in the post-pandemic era?

(3) What can we learn from the past to inform future transitions in the Global South?

(4) What different knowledge has been developed in the Global South that can be transferred to the Global North and Global South to ensure a global, green recovery from the pandemic?

(5) What methodological approaches are best suited for studying and enacting ST in the Global South?

To allow a multiplicity of perspectives from disciplinary, interdisciplinary and transdisciplinary scholars, these questions are intentionally broader than what we asked the panelists of the webinar series. Going beyond the "usual suspects" (sustainability transitions scholars and other interdisciplinary social science scholars), this special issue is open to relevant research on these questions from scholars from all disciplines, such as, but not limited to, economists, sociologists, anthropologists, geographers, development scholars, business and management scholars, policy makers and practitioners.

The REGE special issue on Sustainability Transitions in the Global South, considering post-Covid-19 context and challenges will accept articles on the following (but not limited to) topics:

(1) Rising inequality in times of a pandemic

(2) Changing social practices in times of a pandemic

(3) Local experimentation and innovations in times of a pandemic

(4) Role of state and local/global public institutions in times of a pandemic

(5) Impact on and shifts in informal economy in times of a pandemic 
REGE

28,1

(6) Global comparative policy learning in times of a pandemic

This special issue will be co-edited by our guest editors:

Dr. Bipashyee Ghosh (Science Policy Research Unit, University of Sussex)

Prof. Joyashree Roy (Asian Institute of Technology, Thailand as Bangabandhu Chair Professor)

Katharina Schiller (Fraunhofer Institute for Systems and Innovation Research ISI)

Prof. Mark Swilling (distinguished professor of Sustainable Development in the School of

Public Leadership, University of Stellenbosch (Division Head: Sustainable Development) and co-director of the Stellenbosch Centre for Complex Systems in Transition.

For further information regarding our special issue, please do not hesitate to contact us! Please send an email to transitions.globalsouth@gmail.com with the subject title "Special issue".

\section{Deadlines:}

Manuscripts (up to 8000 words) are expected to be submitted by 30th April, 2021

Review process - up to August 2021

Publication is scheduled for Jan/2022 or earlier, through the ahead of print process.

For further information regarding the submission procedures and other details, please follow the link for the call for papers.

We look forward to your contributions.

Adriana Marotti de Mello

Editor-in-chief - REGE

Bipashyee Ghosh, Joyashree Roy, Katharina Schiller and Mark Swilling

Guest editors

\section{Adriana Marotti de Mello, Katharina Josefa Friedhilde Schiller ${ }^{(\mathbb{D})}$, Bipashyee Ghosh, Joyashree Roy and Mark Swilling}

\section{ORCID iDs}

Katharina Josefa Friedhilde Schiller Dhttp://orcid.org/0000-0003-2196-1719

\section{References}

Belhadi, A., Kamble, S., Jabbour, C.J.C., Gunasekaran, A., Ndubisi, N.O., \& Venkatesh, M. (2020). Manufacturing and service supply chain resilience to the COVID-19 outbreak: Lessons learned from the automobile and airline industries. Technological Forecasting and Social Change. doi: 10. 1016/j.techfore.2020.120447.

Cannon, C. (2020). Foreword. In Pádraig, C., et al. (Eds.), COVID-19 in the Global South: Impacts and Responses. 1st ed. Bristol: Bristol University Press, pp. xix-xxii. Available from: www.jstor.org/ stable/j.ctv18gfz7c.6 (accessed 7 December 2020).

Ghosh, B., \& Schot, J. (2019). Towards a novel regime change framework: Studying mobility transitions in public transport regimes in an Indian megacity. Energy Research and Social Science, 51, 82-95.

Köhler, J., Geels, F.W., Kern, F., Markard, J., Onsongo, E., Wieczorek, A.J., et al. (2019). An agenda for sustainability transitions research: State of the art and future directions. Environmental Innovation and Societal Transitions, 31(December), 1-32, 2018. doi: 10.1016/j.eist.2019.01.004. 
Marx, R., Mello, A.M.M., Zolbovicius, M., \& Lara, F.F. (2015). Spatial contexts and firm strategies: Applying the multilevel perspective to sustainable urban mobility transitions in Brazil. Journal of Cleaner Production, 108(Part A), 1092-1104, 1 December. doi: 10.1016/j.jclepro.2015.09.001.

McMaster, M., Nettleton, C., Tom, C., Xu, B., Cao, C., \& Qiao, P. (2020). Risk management: Rethinking fashion supply chain management for multinational corporations in light of the COVID-19 outbreak. Journal of Risk and Financial Management, 13, 173.

Ramos-Mejía, M., Franco-Garcia, M., \& Jauregui-Becker, J.M. (2018). Sustainability transitions in the developing world: Challenges of socio-technical transformations unfolding in contexts of poverty. Environmental Science and Policy, 84, 217-223. doi: 10.1016/j.envsci.2017.03.010.

Škare, M., Soriano, D.R., \& Porada-Rochoń, M. (2020). Impact of COVID-19 on the travel and tourism industry, technological forecasting and social change. doi: 10.1016/j.techfore.2020.120469.

Swilling, M., \& Annecke, E. (2012). Just transitions: Explorations of Sustainability in An Unfair World. Juta.

\section{Further reading}

Hansen, U.E., Nygaard, I., Romijn, H., Wieczorek, A.J., Kamp, L., \& Klerkx, L. (2018). Sustainability transitions in developing countries: Stocktaking, new contributions and a research agenda. Environmental Science and Policy, 84, 198-203. doi: 10.1016/j.envsci.2017.11.009.

Jenkins, K., Sovacool, B., \& McCauley, D. (2018). Humanizing sociotechnical transitions through energy justice: An ethical framework for global transformative change. Energy Policy, 117(June), $66-67$.

Wieczorek, A.J. (2018). Sustainability transitions in developing countries: Major insights and their implications for research and policy. Environmental Science and Policy, 84(August), 204-216. doi: 10.1016/j.envsci.2017.08.008. 